\title{
Work Motivation of Employees in the Palu City Religious Court Office, Central Sulawesi Province
}

\author{
Abu Rizal Bakri', Mustainah ${ }^{2}$, Shadiq ${ }^{3}$ \\ 1,2,3 Universitas Tadulako \\ E-mail:abakrie169@gmail.com
}

(Received: February-2019; Reviewed: February -2019; Accepted: March-2019;

Avalaibel Online: March 2019; Published: March -2019)

(7) \& This is an open access article distributed under the Creative Commons Attribution License CC-BY-NC-4.0 @2019 by author (https://creativecommons.org/licenses/by-nc/4.0/)

\begin{abstract}
Employees are one of the components that determine and play an important role in the achievement of an work effectiveness in an organization. The purpose of this study is to determine the work motivation of employees at the Religious Court Office in Palu, Central Sulawesi Province, the type of research used is descriptive. While the basic research is qualitative. The number of informants in this study were 5 (five) people. Data collection techniques carried out in 3 (three) ways, namely observation, interviews and documentation. This study uses the theory of Frederick Herzberg, where there are 11 (eleven) aspects studied, namely achievement, appreciation, responsibility, opportunities for advancement, work itself, physical working conditions, interpersonal relations, company policy and administration, supervision, salary, and job security. Research conducted by researchers, obtained the conclusion that the work motivation contained in each employee is good enough, but from every aspect there is not everything can work well in every employee of the Palu City Religious Court, thus affecting the level of motivation in each employee existing and resulting in less than the maximum work activities.
\end{abstract}

Keywords: Motivation; work motivation; civil servants

\section{INTRODUCTION}

Government as a series of institutions has many organizational components with various authorities that are different from each other but are interconnected. Among the three branches of existing government power, executive power has the most institutions (Pradini, 2011; Yani, 2018; Zuhro, 2018). As for the management of legislative and judicial powers, the institutions are more limited than the executive (Badjido \& Samad, 2014).

Civil Servants are located as elements of the state apparatus whose duty is to provide services to the community in a professional, honest, fair and equitable manner in the implementation of state, government and development tasks (Kristiana, 2018; Muslikhun, Hasiolan, \& Fathoni, 2016; Sari, 2017) . Civil servants as bureaucratic apparatus besides being a state apparatus and state servant, are also public servants. So it is to the public interest that the 
bureaucratic apparatus must devote themselves. Bureaucracy is highly expected to have a soul of service and service to the community (Ginting, Rosalina \& Haryati, 2011; Hardiansyah, 2011; Nawawi, 2016).

The state civil servants are required to serve the community to the maximum, but the maximum service provided by the employee depends on how much he is motivated to do the work, in other words every employee must have a high motivation to carry out his work so that it can create good service and good management arrangements (Rosmani, Amirullah, \& Saleh, 2015).

Every person who enters a work environment must have certain goals, and these goals encourage or motivate him to be involved in a work environment. The importance of motivating subordinates because motivation is the cause, channel and support human behavior, so they want to work hard and enthusiastically achieve optimal results. Motivation is increasingly important because managers share work with subordinates to do well and integrated to the desired goals (Sunarsi, 2014, 2017, 2018b, 2018a, 2018c). We need to know that leaders or managers greatly influence a person's motivation to be creative (Amaliyah, Akib, \& Tambe, 2015; Amanurhidayani, Akib, \& Darwis, 2017; Astuti, Saleh, Baharuddin, \& Salam, 2016; Chairil, 2017; Chairil \& Darwis, n.d.; Nasrullah, Salam, Pratiwi, \& Niswaty, 2017).

In this connection it should be noted that a worker does not perform his duties in an atmosphere of emptiness. That is, a person in carrying out the tasks entrusted to him does not limit his presence in the organization only to the completion of the task based on the skills and expressions of the task that may be very clear. (in motivation theory and its application: 127)

Adherence to the various provisions that apply in organizations, make various arrangements in accordance with the traditions and culture of the organization are some other examples of factors that need attention in measuring a person's level of motivation in organizational life. Employees are one component that determines and plays an important role in achieving an effective work within an organization. Because without the employees being the most important element in an organization, as an existing tool and facility it is impossible to be utilized by the organization. So all the tools and facilities that are not possible can be used properly and efficiently for the organization. (Septian Adi Kurnia, 2017).

Intrinsic motivation is when the nature of the work itself makes a person motivated, the person gets satisfaction by doing the work not because of other stimuli such as status or money or it can also be said of a person doing his hobbies. While extrinsic motivation is when the elements outside the work inherent in the work become the main factors that make a person motivated such as status or compensation. (Septian Adi Kurnia, 2017).

Therefore, the theory of Frederick Herberg is used, therefore the factors that cause the motivation of employees must be fulfilled both in intrinsic and extrinsic terms so that the employees of the Palu City Religious Court can work optimally. The technical motivations that need to be met are: achievement, appreciation, responsibility, opportunity to progress, and the work itself. While in terms of extrinsic form: Physical working conditions, interpersonal relations, company policy and administration, supervision, salary, and job security.

\section{METHOD}

This type of research is a qualitative descriptive study. The types of data used are primary data and secondary data. Data collection techniques used are observation, interviews, and documentation. Data analysis consists of data collection, data condensation, data presentation and drawing conclusions. 


\section{RESULT AND DISCUSSION}

Based on the results of research conducted by researchers prove that some motivational factors needed by Religious Court Employees in carrying out the duties and functions of each position they have are quite varied, some require intrinsic motivation, and some require extrinsic motivation.

\section{Achievement}

In this case, achievement is one of the things that encourages an employee in carrying out his work seriously to be able to have a good work performance in managing the work given to the employee, so that in doing all the tasks given to each employee there can be done maximally. Researchers found that in the Locus of the research there was a process of carrying out the tasks given to each employee which was still not good enough in managing the work given to them and sometimes encountered obstacles, but the employees were able to overcome the problem well.

\section{Appreciation}

In this case, the award is a reward given from superiors to subordinates in both material and non-material forms given by the office to their employees so that they can work with high motivation and achievement in achieving the agency's goals. In other words, awarding or rewarding aims to improve productivity and maintain employees who excel in order to remain loyal to the office. Researchers found that in the Locus of the study there was still a lack of rewards to employees who excel and this could lead to a lack of motivation in employees.

\section{Responsible}

In this case, responsibility is a human awareness of behavior or acts both intentional and unintentional. Responsibility also means acting as an expression of awareness of the obligation. Researchers found that in Locus research there were employees who could complete all the work given to them.

\section{A chance to advance}

In this case, one of the encouragement of people to work in an organization is because there is an opportunity to advance. It is the nature of humans in general to be better, more advanced than the position they have today, that's why they want some progress in their lives. Opportunities to progress that are included in the development program can be realized if the Employees are given the opportunity to participate in training and education programs. Researchers found that in the Locus of the study there was still a lack of opportunity to advance in the Palu City Religious Court Office, so that it made it difficult for employees to advance or be promoted to higher positions.

\section{Job itself}

In this case, the work itself or work design is a function of determining the work activities of an individual or group of employees on an organizational basis. The aim is to regulate work 
assignments that meet organizational, technological and behavioral needs. Job design greatly influences the quality of work life, where this is reflected in the satisfaction of individual position holders. Researchers found that in the Locus of the study there was still a lack of real leadership efforts in eliminating the boredom of the employees at work, so that the subordinates felt bored and bored in doing all the work given to them and the motivation created in working was very low.

\section{Physical Working Conditions}

In this case, the physical condition of the work environment around the employee really needs to be considered by the agency, because it is one of the ways that can be taken to ensure that employees can carry out their duties without experiencing interference. Researchers found that in the Locus of research there was still a need to improve existing facilities and facilities, so that the improvement of existing facilities and facilities could support all work activities and motivate employees to work.

\section{Interpersonal Relations}

In this case, interpersonal relations (human relations) are harmonious human relations, the creation of awareness and willingness to fuse individual desires for the integration of common interests. The aim is to produce a fairly solid integration, encouraging productive cooperation. Researchers found that in the Locus of the study there was a good relationship in doing the work done together and the good co-ordination of the positions between each other.

\section{Company Policy and Administration}

In this case, company policy and administration are the decisions and conditions taken by the leader in addressing the Employees in carrying out a job based on the provisions, which are imposed on someone because there are acceptable reasons such as not to enforce applicable rules for something strong reason. Researchers found that in the Locus of the study there was a good decision taken by the leadership, but sometimes the leader also took an unfair decision, so that it could cause disappointment to employees who felt the lack of justice.

\section{Supervision}

In this case, supervision as a component in the management process has an important role in the process of achieving the goals set. If supervision is carried out well, productivity can run well too. Researchers found that in the Locus of the study there was a lack of supervision in the Palu City Religious Court Office, so that it could trigger violations of existing rules and employees could freely violate these rules.

\section{Salary}

In this case, salary is income received by someone and is used to meet their needs. Salary is not the only motivation of employees in achievement, but salary is one of the important motivations that encourage employees to excel, so that the level of salary given will affect employee performance and loyalty. Researchers found that in the Locus of the study, it was good to give honorariums or salaries to each existing ASN, but honorary employees complained 
about the salaries they received each month, so that from the amount of income generated in each month an employee, could affect motivation employee at work.

\section{Job Safety}

In this case, the factor of job security becomes important because it is closely related to employee performance and in turn to organizational performance. Work safety facilities available in the organization will make fewer and fewer chances for work accidents. Researchers found that in Locus research has been fulfilled quite well, both in the spiritual and physical fields.

\section{CONCLUSION}

Based on the results of observation and research conducted by researchers, it can be concluded that the form of work motivation contained in the Palu City Religious Court Office is quite good, because it can be seen from two motivational factors namely: extrinsic factors and intrinsic factors that have been fulfilled well in every employee there.

\section{REFERENCES}

Amaliyah, R., Akib, H., \& Tambe, M. N. (2015). Pengaruh Metode Mengajar Bervariasi Guru Terhadap Motivasi Belajar Siswa Pada Jurusan Administrasi Perkantoran Smk Negeri 1 Makassar. Jurnal Office, 1(2), 198-205.

Amanurhidayani, S. K., Akib, H., \& Darwis, M. (2017). Pengaruh Budaya Organisasi terhadap Motivasi Belajar di SMK YPLP PGRI 1 Makassar The Influence of Organizational Culture on Motivation to Learn in Vocational School YPLP PGRI 1 Makassar. Jurnal Office, 3(2).

Astuti, A., Saleh, S., Baharuddin, A., \& Salam, R. (2016). Studi Motivasi Kerja Pegawai pada PT. Bank Sulselbar Cabang Utama Makassar. JURNAL ILMU ADMINISTRASI PERKANTORAN (JIAP), 79-88.

Badjido, M. Y., \& Samad, A. (2014). Peran pemerintah daerah dalam pemberdayaan masyarakat petani kakao di desa kayuangin kecamatan malunda kabupaten majene. IV(1), $45-54$.

Chairil, A. (2017). Pengaruh Fungsi Kepemimpinan Terhadap Motivasi Kerja Pegawai Padakantor Dinas Pendidikan Kabupaten Sinjai. Jurnal Office, 2(1), 1-8.

Chairil, A., \& Darwis, M. (n.d.). Jamaluddin. 2016."Pengaruh Fungsi Kepemimpinan Terhadap Motivasi Kerja Pegawai Padakantor Dinas Pendidikan Kabupaten Sinjai.” Jurnal Office, 2(1), 2.

Ginting, Rosalina \& Haryati, T. (2011). Reformasi Birokrasi Publik. Jurnal Ilmiah Civis.

Hardiansyah. (2011). Kualitas Pelayanan Publik. Kualitas Pelayanan Publik Menuju Good Local Governance. https://doi.org/10.1016/j.jhsa.2008.07.013

Kristiana, T. (2018). Mutasi Pegawai Negeri Sipil Pada Sekeretaris Badan Litbang Esdm Dengan Metode Promethee. Jurnal Ilmu Pengetahuan dan Teknologi Komputer. 
Muslikhun, Hasiolan, L. B., \& Fathoni, A. (2016). Pengaruh Mekanisme Finger Print, Prosedur Finger Print, Pencapaian Target Finger Print Terhadap Kedisiplinan Pegawai Di Sekretariat Dewan Perwakilan Rakyat Daerah Kota Semarang. Journal of Management.

Nasrullah, M., Salam, R., Pratiwi, D., \& Niswaty, R. (2017). Motivasi Kerja Pegawai Di Kantor Keyahbandaran Utama Makassar. Jurnal Ilmiah Manajemen Dan Bisnis, 18(2), 206-211.

Nawawi, J. (2016). Membangun Kepercayaan dalam Mewujudkan Good Governance. GOVERNMENT : Jurnal Ilmu Pemerintahan.

Pradini, S. S. (2011). Analisis yuridis kekuasaan presiden dalam membentuk undang-undang sebelum dan sesudah amandemen UUD 1945. Jurnal Citizenship.

Rosmani, S. R., Amirullah, A. H., \& Saleh, S. (2015). Pengaruh Motivasi Kerja terhadap Kinerja Pegawai pada Dinas Kebersihan dan Pertamanan Kabupaten Soppeng. Jurnal Office, 1(1), 31-37.

Sari, W. P. (2017). Pengaruh Disiplin Kerja, Komitmen Organisasi, Dan Lingkungan Kerja Terhadap Kinerja Pegawai Negeri Sipil Balai Besar Wilayah Sungai Pemali-Juana. Jurnal Manajemen, UDINUS.

Siagian, S. P. (2013). Filsafat Administrasi. Jakarta: Bumi Aksara.

Sunarsi, D. (2014). Pengaruh Gaya Kepemimpinan, Disiplin dan Motivasi Terhadap Kinerja. Tesis. Fakultas Ekonomi Universitas Pamulang.

Sunarsi, D. (2017). Pengaruh Disiplin, Motivasi, Dan Kompetensi Terhadap Prestasi Belajar (Studi Kasus Pada Mahasiswa Universitas Pamulang, Tangerang Selatan Tahun Akademik 2016-2017). Jurnal Mandiri: Ilmu Pengetahuan, Seni, dan Teknologi, 1(2), 207-226.

Sunarsi, D. (2018a). Analisis Motivasi Kerja Tenaga Pendidik Sukarela Pada Pusat Kegiatan Belajar Masyarakat (PKBM) Bimasda Kota Tangerang Selatan. Kreatif: Jurnal Ilmiah Prodi Manajemen Universitas Pamulang, 6(2), 53-65.

Sunarsi, D. (2018b). Pengaruh Gaya Kepemimpinan, Motivasi Dan Disiplin Kerja Terhadap Kinerja Pendidik Yayasan Marvin. Inovasi, 5(1), 1-18.

Sunarsi, D. (2018c). Pengaruh Motivasi Dan Disiplin Terhadap Produktivitas Kerja Karyawan Pada PT. Nadi Suwarna Bumi. Jurnal Semarak, 1(1).

Terry, G. R., \& Rue, L. W. (1987). Principios de administración. El Ateneo,.

Yani, A. (2018). Sistem Pemerintahan Indonesia: Pendekatan Teori dan Praktek Konstitusi Undang-Undang Dasar 1945. Jurnal Ilmiah Kebijakan Hukum. https://doi.org/10.30641/kebijakan.2018.v12.119-135

Zuhro, S. (2018). Demokrasi, otonomi daerah dan pemerintahan indonesia. Interaktif ilmu-ilmu sosial. 